\title{
The Effect of Peppermint Essential Oil and Nisin on Listeria monocytogenes Inoculated in Minced Meat of Silver Carp
}

\author{
Afsaneh Nouri Jangi ${ }^{1, *}(\mathbb{D})$, Ebrahim Alizadeh Dooghikalaei ${ }^{2}{ }^{(D}$, Majid Alipour \\ Eskandani $^{3}$
}

${ }^{1}$ University of Zabol, Faculty of Natural Resources, Department of Shilat, Zabol, Iran.

2University of Zabol, Department of Shilat, Zabol, Iran.

${ }^{3}$ University of Zabol, Faculty of Veterinary Medicine, Zabol, Iran.

\section{How to cite}

Jangi, A.N., Dooghikalaei, E.A., Eskandani, M.A. (2021). The Effect of Peppermint Essential Oil and Nisin on Listeria monocytogenes Inoculated in Minced Meat of Silver Carp. Aquatic Food Studies, 1(2), AFS63. https://doi.org/10.4194/AFS63

\section{Article History}

Received 08 November 2021

Accepted 30 December 2021

First Online 05 January 2022

\section{Corresponding Author \\ Tel.: +0540151443497 \\ E-mail: afsanenouri2007@gmail.com}

\section{Keywords}

L. monocytogenes

Nisin

Peppermint essential oil

Inhibitory-bacterial property

Silver carp

\begin{abstract}
Listeria monocytogenes is one of the most important food-borne pathogenic bacteria and now its control is the most important challenge in food industry plants. The aim of this study was to evaluate the effect of peppermint essential oil and Nisin in controlling the growth of $L$. monocytogenes in minced meat of silver carp in the first, L. monocytogenes bacteria $(3 \mathrm{log} / \mathrm{g})$ were inoculated to minced meat of silver carp, then peppermint essential oil $(0 / 005$ to $4 \%)$ and Nisin $(2.5$ to $70 \mu \mathrm{g} / \mathrm{g})$ were added to samples separately as well as in various concentrations in order to inhibit of $L$. monocytogenes bacteria. L. monocytogenes was counted in $0,1,3,5,7,9,12,15$, and 21 days during storage refrigerator. The results showed that in the separate concentration, adding $4 \%$ of peppermint essential oil and $40 \mu \mathrm{g} / \mathrm{g}$ of Nisin on minced meat of silver carp were effective. On the other hand, the combination of $0.5 \%$ peppermint essential oil and $40 \mathrm{\mu g} / \mathrm{g}$ of Nisin had excellent inhibitory effects on the growth of L. monocytogenes. Therefore, the results indicated that peppermint essential oil and Nisin could be used as a natural preservative in controlling and inhibiting of $L$. monocytogenes bacteria.
\end{abstract}

\section{Introduction}

Food-borne diseases as a result of consumption of foods contaminated to spoilage and pathogenic bacteria directly play role in public health (Oussalah et al., 2007). The use of chemicals to prevent or delay food spoilage is now very widely. In connection with the adverse effects of industrial chemicals, convincing arguments have been made on carcinogenicity and their toxicity for humans. For this reason, food manufacturers and consumers must take caution in the use of these preservatives (Skandamis et al., 2001). Fortunately, because of increase in consumers' awareness in the international community level, there is a growing interest in the use of natural preservatives and antibiotics such as essential oils and Nisin, respectively (Schuenzel and Harrison 2002). L. monocytogenes is a small rod Gram-positive bacteria and is sensitive to high temperatures (Bell and Kyriakides, 2005). These bacteria are spread widely in different parts (Dhanashree et al., 2008; Curtis, 2000). Their cells are able to be survived in dry, wet, salty conditions and oxygen-free environments (Dillon et al., 2003). Although a direct link between the prevalence of $L$. monocytogenes and sea food contamination is not reported, but these bacteria have been isolated from raw and processed marine products (Dillon et al., 2003). Generally, L. monocytogenes bacteria have a special importance from the view of 
food poisoning and Listeriosis disease which creates in humans (Farber, 2000b).

Bacteriocins such as Nisin are bactericidal proteins which their production by lactic acid bacteria have been widely studied in recent years. With regard to the fact that these compounds are produced by the useful organisms available in food, natural preservatives title are attributed to them; therefore, they have more acceptance as natural bio preservatives of foods. Naysin is a type of polypeptide bacteriocins that containing thirty-four amino acids. It is produced by certain strains of Lactococcus lactis, a subspecies of lactis. Itis also used as a food preservative in food industry due to its antimicrobial properties and low toxicity for humans for a long time (Smid and Corris, 1999 and Kuwano et al., 2005). The Nisin is only bacteriocin that has a wide practical application in the food industry with the adoption of the World Health organization (DelvesBroughton and Gasson, 1994). Because the bacteriocin such as Nisin prevents the growth of Gram-positive bacteria and prevalence of Clostridium and Bacillus spores. In fact Niacin disrupts the cell membrane of the bacteria by creating pores in it, and increases the lipid II in the bacterial membrane and its sensitivity (Smid and Corris, 1999 and Duarte et al., 2005 and Breukink et al., 1999).Investigation of the combination effects of Nisin and essential oils have promising results; although this research is still in its infancy (Misaghi et al., 2007).It should be noted, in recent years the use of herbal essential oils in raw foods, especially processed food have increased as a good alternative to synthetic preservatives and chemical additives (Tyagi et al., 2012 and Noriega et al., 2010).

Peppermint with its scientific name as Menthapiperita $L$ belongs to the Lamiaceae family (Bupesh et al., 2007 and Leung and Foster1996). This herb is a hybrid species and is achieved from the cross between Menthaaquatica and Spicata (Peirce, 1999). It is native to temperate regions of the world, particularly Europe, North America and North Africa, but is now cultivated throughout the world (Singh et al., 2011). This mint species is considered as one of the most important medicinal plants and contain many essential oils and has high economic value (Ma et al., 2004). In traditional medicine, dried peppermint and its essential oils is also used to reduce appetite, colds, cough, fever, nausea, and headache. On the other hands, it has antispasmodic, carminative and dyspepsia good effects (Sousa et al., 2010 and Leung and Foster, 1996). Essential oil of peppermint is as valuable as peppermint itself. Because, it due to containing compounds such as cineole, limonene, linalool and menthol, has antibacterial and antiviral activities (Duarte, 2005). Menthol is the main component of peppermint essential oil, which is part of Monoterpenes. Therefore, considering the good features mentioned above, the purpose of this study was to evaluate the antibacterial properties of peppermint essential oil and Nisin on L. monocytogenes in minced meat of silver carp.

\section{Materials and Methods}

\section{Nisin Preparation}

Nisin containing $2.5 \%$ active Nisin was purchased from SIGMA-ALDRICH Company. Nisinstoke was prepared using $0.02 \mathrm{M} / \mathrm{L}$ of $\mathrm{HCland} \mathrm{pH}$ 1.6. Then it was filtered by the disposable sterilized microfilter and syringe (Misaghi and Basti, 2007).

\section{Peppermint Essential Oil Preparation}

For extracting and measuring of the essential oil, the peppermints were dried at room temperature (about $25^{\circ} \mathrm{C}$ ) and in the shade. Then essence extraction was performed using Clevenger apparatus and distillation method. Determining the essential oil compounds was performed using GC/MS apparatus. Briefly, $100 \mathrm{~g}$ of each dried sample were grinded and essence extraction (Gerhart) was performed and its percentage was determined using distillation method for two hours [24].Ingredients of the commercial compound were analyzed by gas chromatography equipped with a mass spectrometer (GC/MS), gas chromatography (GC) of Agilent 7890 model connected with the mass spectrometer (Mass) model (Agilent 5975) HP-5MS column and semi-polar with length of 30 meters, internal diameter of the column equal to $25 \mathrm{MS}$, $\mathrm{MS}$ detector, carrier gas of helium $(\mathrm{He})$, flow equal to 1 $\mathrm{mL}$ per minute, the temperature program of $60-225^{\circ} \mathrm{C}$ with speed of $4{ }^{\circ} \mathrm{C} / \mathrm{min}$ and the Injection chamber temperature of $270{ }^{\circ} \mathrm{C}$ at the scholars Institute of Tehran. After oil injection to mentioned devices, using the retention times of the compounds retention indices (RT) of the mass spectrum and comparison of these parameters with standard compounds and/or with the available information contained in the library in order to identify the essential oil compounds were performed. A small percentage of these compounds have also been calculated by calculating the levels under the curve in chromatography.

\section{L. monocytogenes Preparation for Inoculation}

Standard and lyophilized strains of bacteria $L$. monocytogenes PTCC 1163 were prepared from Scientific and Industrial Research Organization of Iran. Vials of lyophilized bacteria were first opened in sterile conditions, then were transferred to the Tryptic Soy Broth (TSB) and incubated for $41 \mathrm{~h}$ in $30^{\circ} \mathrm{C}$. The cultures containing the bacteria were centrifuged for $5 \mathrm{~min}$. The supernatant was replaced with Ringer's solution. In order to complete separation of medium from bacteria, the resulting solution was centrifuged again for $5 \mathrm{~min}$. The number of bacteria in below liquid was obtained by turbidity test at a wavelength of $570 \mathrm{~nm}$; so that the light absorption of 0.08 to 0.1 approximately equal to $1 \times$ $10^{8}$ bacteria/ $\mathrm{ml}$ was considered. In order to achieve this range of light absorption, dilution with sterile Ringer was 
done. To confirm the results, bacteria were counted by the method of surface culture on Mueller-Hinton agar (24 h incubation at $37^{\circ} \mathrm{C}$ ).

\section{Preparation of Silver Carp Paste}

First, $10 \mathrm{~kg}$ of Silver carp (Hypophthalmichthys molitrix) were fished from fish farms and put into boxes containing ice; Then were transferred to the microbiology laboratory of Faculty of Veterinary Medicine. The peeled operation was performed after washing fishes. The underside of the meat was removed without touching the viscera and minced twice by a meat grinder. After that, CFU/g $1 \times 10^{3}$ bacteria were inoculated to the samples of minced fish meat (Roomiani, 2012). Inoculated meat samples were completely homogenized. The inoculated meat was used to prepare all experimental treatments.

\section{Treatment and Counting L. monocytogenes Bacteria During Storage}

Inoculated meats of control sample and peppermint essential oils $(4,3,2,1,0 / 5,0 / 3,0 / 2,0 / 15$, $0 / 1,0 / 09,0.03,0 / 015,0.005 \%)$ and Nisin $(2 / 5,5,7 / 5$, $10,15,20,30,40,50,60,70 \mu \mathrm{g} / \mathrm{g}$ ) separately were prepared. Also, the combination of Nisin $(\mu \mathrm{g} / \mathrm{g})$ and peppermint essential oil (\%) were prepared following condition:

(2/5 $\mathrm{\mu g} / \mathrm{g}+0 / 005 \%),(0 / 015 \mu \mathrm{g} / \mathrm{g}+2 / 5 \%),(0 / 03 \mu \mathrm{g} / \mathrm{g}$ $+2 / 5 \%)$, (0/06 $\mu \mathrm{g} / \mathrm{g}+2 / 5 \%),(0 / 09 \mu \mathrm{g} / \mathrm{g}+2 / 5 \%),(0 / 1$ $\mu \mathrm{g} / \mathrm{g}+2 / 5 \%)$, (0/15 $\mu \mathrm{g} / \mathrm{g}+2 / 5 \%),(0 / 2 \mu \mathrm{g} / \mathrm{g}+2 / 5 \%)$, (0/06 $\mathrm{gg} / \mathrm{g}+4 \%),(0 / 09 \mu \mathrm{g} / \mathrm{g}+4 \%),(0 / 5 \mu \mathrm{g} / \mathrm{g}+10 \%)$, $(0 / 5 \mu \mathrm{g} / \mathrm{g}+20 \%),(0 / 5 \mu \mathrm{g} / \mathrm{g}+30 \%),(1 \mu \mathrm{g} / \mathrm{g}+30 \%)$ and $(2 \mu \mathrm{g} / \mathrm{g}+30 \%)$

In order to count L. monocytogenes, Chromogenic selective medium culture CHROM agar, Microbiology
Company of France) and its complement (CHROM agar Listeria supplement) were used (Murdock, 2007). L. monocytogeneswas counted every $41 \mathrm{~h}$. For bacteria counting, $45 \mathrm{ml}$ of physiology serum was added to $5 \mathrm{~g}$ of minced fish meat and homogenized. Focounting bacteria, serial dilutions (1:10) was prepared. $0.1 \mathrm{ml}$ of the diluted sample of Listeria TM was cultured on the CHROMagar medium culture and was incubated for 24 $\mathrm{h}$ at $37^{\circ} \mathrm{C}$. L. monocytogenes formed blue colonies with white halos in the Cultureenvironment. For each treatment two repeat were consideredwhich were counted after standard plates culturing.

\section{Statistical Analysis}

Statistical analysis of data was done using SPSS 17 software. Statistical tests such as Kolmogorov-Smirnov and one-way ANOVA, as well as means comparison was done by Duncan test (Yin, L et al., 2007).

\section{Result}

\section{The Chemical Composition of Peppermint Essential Oil}

Identified compounds of peppermint essential oil are shown in Table 1 . The main combinations presences in it were 42/96 \% menthol, 18/43\% Menton and 6/24 $\%$ Mentophoran. Generally, The Results showed that the number of $L$. monocytogenes cells affected by different concentrations of peppermint essential oil in minced silver carp meat on day zero was $1 \times 10^{3} \mathrm{CFU} / \mathrm{g}$ (Table 2). The number of Listeria bacteria in the control samples increased during storagetime. On the first day of maintenance the number of treatments' bacteria containing peppermint essential oil showed statistically significant decrease compared to the control samples $(p<0.05)$. On the third day of maintenance the numbers of Listeria bacteria were uncountable in control samples and in concentrations of $0.015 \%$ and $0.005 \%$ from

Table 1. The chemical composition of peppermint essential oil by GC / MS

\begin{tabular}{|c|c|c|c|c|c|}
\hline Number & $\begin{array}{c}\text { Chemical } \\
\text { composition }\end{array}$ & $\begin{array}{c}\text { Percentage of essential } \\
\text { oils }\end{array}$ & Number & $\begin{array}{c}\text { Chemical } \\
\text { composition }\end{array}$ & $\begin{array}{c}\text { Percentage of essential } \\
\text { oils }\end{array}$ \\
\hline 1 & $\alpha$-Pinene & $0 / 28$ & 17 & Sabinene & $0 / 27$ \\
\hline 2 & $\beta$-Pinene & $0 / 39$ & 18 & gamma-Terpinene & $0 / 27$ \\
\hline 3 & $\beta$-Myrcene & $0 / 24$ & 19 & Menthyl acetate & $2 / 76$ \\
\hline 4 & Limonene & $1 / 09$ & 20 & Menthol acetate & $0 / 72$ \\
\hline 5 & 1,8-Cineol & $3 / 56$ & 21 & Viridiflorol & $0 / 96$ \\
\hline 6 & Menthol & $42 / 96$ & 22 & Somintlactone & $1 / 02$ \\
\hline 7 & Camphene & $0 / 6$ & 23 & Farnesene & $0 / 29$ \\
\hline 8 & Tymol & $0 / 25$ & 24 & $\alpha$-Humulene & $0 / 18$ \\
\hline 9 & Pulegone & $3 / 83$ & 25 & $\beta$-Bourbonene & $0 / 35$ \\
\hline 10 & neo-Menthol & $2 / 13$ & 26 & Octanol & $0 / 21$ \\
\hline 11 & Neoisomenthol & $0 / 56$ & 27 & Ethylamylcarbinol & $0 / 62$ \\
\hline 12 & Menthone & $18 / 43$ & 28 & Spathulenol & $0 / 27$ \\
\hline 13 & $\alpha$-Terpineol & $0 / 22$ & 29 & isospathulenol & $0 / 26$ \\
\hline 14 & Menthofuran & $6 / 24$ & 30 & Caryophyllene oxide & $0 / 95$ \\
\hline 15 & Carvacrol & $1 / 34$ & 31 & Carvomenthenone & $1 / 49$ \\
\hline 16 & Borneol & $0 / 1$ & 32 & cis-sabinene hydrate & $0 / 25$ \\
\hline
\end{tabular}


Table 2. The number of vegetative cells of L. monocytogenes under different concentrations of peppermint essential oil (\%) in minced silver carp meat during 21 days storage at refrigerator temperature $\left(4^{\circ} \mathrm{C}\right)$

\begin{tabular}{|c|c|c|c|c|c|c|c|c|c|}
\hline \multicolumn{10}{|c|}{ Time (days) } \\
\hline Peppermint essential oil (\%) & 0 & 1 & 3 & 5 & 7 & 9 & 12 & 15 & 21 \\
\hline Control & $3.00 \pm 0.00 \mathrm{Ab}$ & $8.37 \pm 0.02 \mathrm{Aa}$ & TNTC & TNTC & TNTC & TNTC & TNTC & TNTC & TNTC \\
\hline 0.005 & $3.00 \pm 0.00 \mathrm{Ab}$ & $8.30 \pm 0.01 \mathrm{Ba}$ & TNTC & TNTC & TNTC & TNTC & & TNTC & TNTC \\
\hline 0.015 & $3.00 \pm 0.00 \mathrm{Ab}$ & $7.10 \pm 0.01 \mathrm{Ca}$ & TNTC & TNTC & TNTC & TNTC & TNTC & TNTC & TNTC \\
\hline 0.03 & $3.00 \pm 0.00 A c$ & $6.44 \pm 0.01 \mathrm{DB}$ & $7.40 \pm 0.01 \mathrm{Ba}$ & TNTC & TNTC & TNTC & TNTC & TNTC & TNTC \\
\hline 0.06 & $3.00 \pm 0.00 A c$ & $6.17 \pm 0.04 \mathrm{~Eb}$ & $7.41 \pm 0.01 \mathrm{Ba}$ & TNTC & TNTC & TNTC & TNTC & TNTC & TNTC \\
\hline 0.09 & $3.00 \pm 0.00 \mathrm{Ac}$ & $6.11 \pm 0.01 \mathrm{Fb}$ & $7.41 \pm 0.01 \mathrm{Ba}$ & TNTC & TNTC & TNTC & TNTC & TNTC & TNTC \\
\hline 0.1 & $3.00 \pm 0.00 A c$ & $6.03 \pm 0.05 \mathrm{~Gb}$ & $7.30 \pm 0.01 \mathrm{Ca}$ & TNTC & TNTC & TNTC & TNTC & TNTC & TNTC \\
\hline 0.15 & $3.00 \pm 0.00 A c$ & $5.77 \pm 0.01 \mathrm{Hb}$ & $7.21 \pm 0.02 \mathrm{Da}$ & TNTC & TNTC & TNTC & TNTC & TNTC & TNTC \\
\hline 0.2 & $3.00 \pm 0.00 A c$ & $5.60 \pm 0.01 \mathrm{lb}$ & $7.21 \pm 0.02 \mathrm{Da}$ & TNTC & TNTC & TNTC & TNTC & TNTC & TNTC \\
\hline 0.3 & $3.00 \pm 0.00 A c$ & $5.60 \pm 0.01 \mathrm{lb}$ & $7.11 \pm 0.01 \mathrm{Ea}$ & TNTC & TNTC & TNTC & TNTC & TNTC & TNTC \\
\hline 0.5 & $3.00 \pm 0.00 A c$ & $5.41 \pm 0.02 \mathrm{lb}$ & $7.01 \pm 0.01 \mathrm{Fa}$ & TNTC & TNTC & TNTC & TNTC & TNTC & TNTC \\
\hline 1 & $3.00 \pm 0.00 A c$ & $5.30 \pm 0.01 \mathrm{~Kb}$ & $7.16 \pm 0.27 \mathrm{DEa}$ & TNTC & TNTC & TNTC & TNTC & TNTC & TNTC \\
\hline 2 & $3.00 \pm 0.00 A c$ & $5.30 \pm 0.01 \mathrm{~Kb}$ & $7.23 \pm 0.1 \mathrm{Da}$ & TNTC & TNTC & TNTC & TNTC & TNTC & TNTC \\
\hline 3 & $3.00 \pm 0.00 A c$ & $3.32 \pm 0.43 \mathrm{Lc}$ & $7.47 \pm 0.01 \mathrm{Ab}$ & $7.55 \pm 0.07 \mathrm{Ab}$ & TNTC & TNTC & TNTC & TNTC & TNTC \\
\hline 4 & $3.00 \pm 0.00 \mathrm{Aa}$ & $3.01 \pm 0.02 \mathrm{Ma}$ & 0 & 0 & 0 & 0 & 0 & 0 & 0 \\
\hline
\end{tabular}

Values represent the mean \pm standard deviation of three repetitions.

Different capital letters $(A, B, C)$ in each row represents a meaningful difference between treatments $(p<0.05)$.

Different small letters $(a, b, c)$ in each column represents a meaningful difference between storage times $(p<0.05)$.

TNTC: uncountable.

peppermint essential oil. Other treatments had a meaningful and weak inhibitory effect against Listeria. Only $4 \%$ of the peppermint essential oil became inhibited bacterial growth and decreased the bacteria numbers to zero $(p<0.05)$. Also, $3 \%$ of the peppermint essential oil showed a weak inhibitory effect on the fifth day. The number of bacteria became uncountable on the seventh day. The results of the number of $L$. monocytogenes bacteria affected by different concentration of Nisin in minced silver carp meat are shown in table 3 . The total number of $L$. monocytogenes bacteria in minced silver carp meat in day zero was $1 \times 10^{3} \mathrm{CFU} / \mathrm{g}$ (Table 3 ). With the passage of time the number of bacteria in the control samples lacking Nisin had increasing. On the first day of maintenance the number of Listeria bacteria containing Nisin was significantly lower than the control samples $(p<0.05)$. On the third day of maintenance the number of Listeria bacteria were in control samples became uncountable. The rest of the treatments showed meaningful inhibitory effect against Listeria bacteria. Nisin treatments in concentrations of $40,50,60,70 \mu \mathrm{g} / \mathrm{g}$, inhibited the growth of bacteria and decreased the number of bacteria to zero $(p<0.05)$. On the fifth day, only Nisin treatments in concentrations of 15, 20, 30 $\mu \mathrm{g} / \mathrm{g}$ showed a weak effect and the difference was meaningful $(p<0.05)$. On the 7 th to 21th day, there was a meaningful difference between Nisin treatments in concentrations of 20 and $30 \mu \mathrm{g} / \mathrm{g}$, but they showed a weak and meaningful inhibitory effect $(p<0.05)$. The results of the number of L.monocytogenes cells affected by different concentrations of Nisin and peppermint essential oil in minced silver carp meat are also shown in table 4. The total number of L.monocytogenes bacteria in minced silver carp meat on day zero was $1 \times$ $10^{3} \mathrm{CFU} / \mathrm{g}$ (Table 2).On the first day, the number of $L$. monocytogenesbacteria in treatments containing Nisin and peppermint essential oil had significant difference compared to control samples $(p<0.05)$. On the third day, the number of $L$. monocytogenes bacteria in treatments containing Nisin and peppermint essential oil decreased significantly compared to the control samples $(p<0.05)$. Also, the number of Listeria bacteria were in control samples became uncountable. On the other hands, on the 3th day of storage, treatments containing combination of Nisin and peppermint essential oil (30 $\mu \mathrm{g} / \mathrm{g}+0.5 \%),(30 \mu \mathrm{g} / \mathrm{g}+1 \%)$, and $30 \mu \mathrm{g} / \mathrm{g}+2 \%)$ decreased the number of $L$. monocytogenes bacteria to zero. On the fifth day storage, there was a weak inhibitory effect and a meaningful difference between treatments $(p<0.05)$. But the treatment containing Nisin and peppermint essential oil $(20 \mu \mathrm{g} / \mathrm{g}+0.5 \%)$ caused the number of bacteria to become $2 \log$. On the seventh day storage, the number of $L$. monocytogenesbacteria in all treatments became uncountable and the number of bacteria reached to zero in the treatment containing Nisin and peppermint $(20 \mu \mathrm{g} / \mathrm{g}+0.5 \%)$.

\section{Discussion}

The results of this study showed that in comparison with reported results in different studies is somewhat complex. One of reasons is due to different methods on their antibacterial properties, different characteristics of various bacterial strings and the culture medium. Using multi-inhibitory parameters is a useful method for reducing concentration of preservatives in foods. Both Nisin and peppermint essential oils can influence on the cell membrane of bacteria. In fact, Nisin causes difficulties in the exchange of materials such as ATP and ADP by impacting on the cytoplasmic membrane of microorganisms and creating pores in the membrane. Also forming pores in the cell membrane by effect on driving force of positive load of cells and causing the 
Table 3. The number of vegetative cells of $L$. monocytogenes under different concentrations of Nisin $(\mu \mathrm{g} / \mathrm{g})$ in minced silver carp meat during 21 days storage at refrigerator temperature $\left(4^{\circ} \mathrm{C}\right)$.

\begin{tabular}{|c|c|c|c|c|c|c|c|c|c|}
\hline \multicolumn{10}{|c|}{ Time (days) } \\
\hline $\operatorname{Nisin}(\mu \mathrm{g} / \mathrm{g})$ & 0 & 1 & 3 & 5 & 7 & 9 & 12 & 15 & 21 \\
\hline & $3.00 \pm 0.00 \mathrm{Ab}$ & $8.37 \pm 0.02 \mathrm{Aa}$ & TNTC & TNTC & TNTC & TNTC & TNTC & TNTC & TNTC \\
\hline 2.5 & $3.00 \pm 0.00 A c$ & $5.46 \pm 0.39 \mathrm{Cb}$ & $7.65 \pm 0.09 \mathrm{Aa}$ & TNTC & TNTC & TNTC & TNTC & TNTC & TNTC \\
\hline 5 & $3.00 \pm 0.00 \mathrm{Ac}$ & $5.56 \pm 0.39 \mathrm{BCb}$ & $7.43 \pm 0.01 \mathrm{Ba}$ & TNTC & TNTC & TNTC & TNTC & TNTC & TNTC \\
\hline 7.5 & $3.00 \pm 0.00 A c$ & $5.5 \pm 0.01 \mathrm{Cb}$ & $7.38 \pm 0.6 \mathrm{BCa}$ & TNTC & TNTC & TNTC & TNTC & TNTC & TNTC \\
\hline 10 & $3.00 \pm 0.00 \mathrm{Ac}$ & $3.58 \pm 0.01 \mathrm{Db}$ & $7.30 \pm 0.01 \mathrm{Ca}$ & TNTC & TNTC & TNTC & TNTC & TNTC & TNTC \\
\hline 15 & $3.00 \pm 0.00 A c$ & $3.46 \pm 0.01 \mathrm{Ec}$ & $6.61 \pm 0.02 \mathrm{Dh}$ & $7.43 \pm 0.04 \mathrm{Aa}$ & TNTC & TNTC & TNTC & TNTC & TNTC \\
\hline 20 & $3.00 \pm 0.00 \mathrm{Ah}$ & $3.25 \pm 0.01 \mathrm{Dg}$ & $5.47 \pm 0.01 \mathrm{Ef}$ & $5.61 \pm 0.01 \mathrm{Be}$ & $6.31 \pm 0.02 \mathrm{Ad}$ & $6.31 \pm 0.02 \mathrm{Ad}$ & $6.97 \pm 0.01 \mathrm{Ac}$ & $7.17 \pm 0.00 \mathrm{Ab}$ & $7.46 \pm 0.02 \mathrm{~A}$ \\
\hline 30 & $3.00 \pm 0.00 \mathrm{Ae}$ & $3.00 \pm 0.01 \mathrm{Ge}$ & $3.00 \pm 0.00 \mathrm{Fe}$ & $5.05 \pm 0.02 \mathrm{Cd}$ & $5.12 \pm 0.01 \mathrm{BC}$ & $5.78 \pm 0.01 \mathrm{Bb}$ & $6.39 \pm 0.02 \mathrm{Ba}$ & $6.38 \pm 0.01 \mathrm{Ba}$ & $6.38 \pm 0.01 \mathrm{Ba}$ \\
\hline 40 & $3.00 \pm 0.00 \mathrm{Aa}$ & $2.60 \pm 0.01 \mathrm{Hb}$ & 0 & 0 & 0 & 0 & 0 & 0 & 0 \\
\hline 50 & $3.00 \pm 0.00 \mathrm{Aa}$ & $2.48 \pm 0.01 \mathrm{lb}$ & 0 & 0 & 0 & 0 & 0 & 0 & 0 \\
\hline 60 & $3.00 \pm 0.00 \mathrm{Aa}$ & $2.30 \pm 0.02 \mathrm{Jb}$ & 0 & 0 & 0 & 0 & 0 & 0 & 0 \\
\hline 70 & $3.00 \pm 0.00 \mathrm{Aa}$ & $2.13 \pm 0.01 \mathrm{~Kb}$ & 0 & 0 & 0 & 0 & 0 & 0 & 0 \\
\hline
\end{tabular}

Values represent the mean \pm standard deviation of three repetitions.

Different capital letters $(A, B, C)$ in each row represents a meaningful difference between treatments $(p<0.05)$

Different small letters $(a, b, c)$ in each column represents a meaningful difference between storage times $(p<0.05)$

TNTC: uncountable.

Table 4. The number of vegetative cells of $L$. monocytogenes under different concentrations of Nisin $(\mu \mathrm{g} / \mathrm{g})$ and peppermint essential oil (\%) in minced silver carp meat during 21 days storage at refrigerator temperature $\left(4^{\circ} \mathrm{C}\right)$.

\begin{tabular}{|c|c|c|c|c|c|c|c|c|c|}
\hline \multicolumn{10}{|c|}{ Time (days) } \\
\hline Essential oil $(\%) / N i s i n(\mu \mathrm{g} / \mathrm{g})$ & 0 & 1 & 3 & 5 & 7 & 9 & 12 & 15 & 21 \\
\hline Control & $3.00 \pm 0.00 \mathrm{Ab}$ & $8.37 \pm 0.02 \mathrm{Aa}$ & TNTC & TNTC & TNTC & TNTC & TNTC & TNTC & TNTC \\
\hline$\% 0.005+2.5$ & $3.00 \pm 0.00 \mathrm{Ad}$ & $4.86 \pm 0.01 \mathrm{Bc}$ & $8.41 \pm 0.01 \mathrm{Ab}$ & $8.50 \pm 0.01 \mathrm{Aa}$ & TNTC & TNTC & TNTC & TNTC & TNTC \\
\hline$\% 0.015+2.5$ & $3.00 \pm 0.00 \mathrm{Ad}$ & $4.84 \pm 0.01 \mathrm{Bc}$ & $8.42 \pm 0.02 \mathrm{Ab}$ & $8.52 \pm 0.01 \mathrm{Aa}$ & TNTC & TNTC & TNTC & TNTC & TNTC \\
\hline$\% 0.03+2.5$ & $3.00 \pm 0.00 \mathrm{Ad}$ & $4.76 \pm 0.01 \mathrm{BCC}$ & $7.50 \pm 0.1 \mathrm{Bb}$ & $7.61 \pm 0.01 \mathrm{Ba}$ & TNTC & TNTC & TNTC & TNTC & TNTC \\
\hline$\% 0.06+2.5$ & $3.00 \pm 0.00 \mathrm{Ad}$ & $4.71 \pm 0.02 \mathrm{Cc}$ & $7.52 \pm 0.01 \mathrm{Bb}$ & $7.62 \pm 0.02 \mathrm{Ba}$ & TNTC & TNTC & TNTC & TNTC & TNTC \\
\hline$\% 0.09+2.5$ & $3.00 \pm 0.00 \mathrm{Ad}$ & $4.71 \pm 0.01 \mathrm{Cc}$ & $7.51 \pm 0.01 \mathrm{Bb}$ & $7.61 \pm 0.01 \mathrm{Ba}$ & TNTC & TNTC & TNTC & TNTC & TNTC \\
\hline$\% 0.1+2.5$ & $3.00 \pm 0.00 \mathrm{Ad}$ & $4.60 \pm 0.01 \mathrm{Dc}$ & $7.50 \pm 0.02 \mathrm{Bb}$ & $7.61 \pm 0.01 \mathrm{Ba}$ & TNTC & TNTC & TNTC & TNTC & TNTC \\
\hline$\% 0.15+2.5$ & $3.00 \pm 0.00 \mathrm{Ad}$ & $4.5 \pm 0.00 \mathrm{Ec}$ & $7.5 \pm 0.01 \mathrm{Bb}$ & $7.60 \pm 0.01 \mathrm{Ba}$ & TNTC & TNTC & TNTC & TNTC & TNTC \\
\hline$\% 0.2+2.5$ & $3.00 \pm 0.00 \mathrm{Ad}$ & $4.41 \pm 0.02 \mathrm{Fc}$ & $7.51 \pm 0.01 \mathrm{Bb}$ & $7.61 \pm 0.02 \mathrm{Ba}$ & TNTC & TNTC & TNTC & TNTC & TNTC \\
\hline$\% 0.06+4$ & $3.00 \pm 0.00 \mathrm{Ad}$ & $3.5 \pm 0.01 \mathrm{Gc}$ & $7.21 \pm 0.01 \mathrm{Cb}$ & $7.30 \pm 0.01 \mathrm{Ca}$ & TNTC & TNTC & TNTC & TNTC & TNTC \\
\hline$\% 0.09+4$ & $3.00 \pm 0.00 \mathrm{Ad}$ & $3.48 \pm 0.01 \mathrm{Gc}$ & $7.21 \pm 0.02 \mathrm{Cb}$ & $7.31 \pm 0.01 \mathrm{Ca}$ & TNTC & TNTC & TNTC & TNTC & TNTC \\
\hline$\% 0.5+10$ & $3.00 \pm 0.00 \mathrm{Ad}$ & $3.31 \pm 0.27 \mathrm{Hc}$ & $7.10 \pm 0.01 \mathrm{Db}$ & $7.21 \pm 0.01 \mathrm{Da}$ & TNTC & TNTC & TNTC & TNTC & TNTC \\
\hline$\% 0.5+20$ & $3.00 \pm 0.00 \mathrm{Aa}$ & $2.70 \pm 0.01 \mathrm{lb}$ & $2.60 \pm 0.01 \mathrm{Ec}$ & $2.00 \pm 0.00 \mathrm{Ed}$ & TNTC & TNTC & TNTC & TNTC & TNTC \\
\hline$\% 0.5+30$ & $3.00 \pm 0.00 A a$ & $2.30 \pm 0.01 \mathrm{Jb}$ & 0 & 0 & 0 & 0 & 0 & 0 & 0 \\
\hline$\% 1+30$ & $3.00 \pm 0.00 \mathrm{Aa}$ & $2.06 \pm 0.11 \mathrm{~Kb}$ & 0 & 0 & 0 & 0 & 0 & 0 & 0 \\
\hline$\% 2+30$ & $3.00 \pm 0.00 \mathrm{Aa}$ & $1.10 \pm 0.17 \mathrm{Lb}$ & 0 & 0 & 0 & 0 & 0 & 0 & 0 \\
\hline
\end{tabular}

Values represent the mean \pm standard deviation of three repetitions.

Different capital letters $(A, B, C)$ in each row represents a meaningful difference between treatments $(p<0.05)$

Different small letters $(a, b, c)$ in each column represents a meaningful difference between storage times $(p<0.05)$

TNTC: uncountab

death of microorganisms (De Arauza et al.,2009). Besides, the hydrophobic properties of peppermint essential oils also allow this combination easily penetrates to the lipid membrane and causes the leak out of this material inside bacteria and ultimately their death occurs (Boziaris et al.,2006). Using peppermint essential oil along with Nisin alleviates the limitations of using this substance, because Nisin is a combination that has little solubility in water and also its most effect is in acidic conditions. Another limitation of the use of Nisin is that many bacteria such as some strains of L. monocytogenes are resistant to it (Boziaris et al.,2006). The results of this study indicate that by the combination of these two materials can be overcome the problems of using Nisin.

Various differences presence in reports of inhibitory concentrations of peppermint essential oil and Nisin are due to differences in species of peppermint, bacteria strains, and the type of used medium (Murdock, 2007 and. Yin et al. 2007) used
Naysin and Pediosin at different levels between 375 to $7500 \mathrm{IU} / \mathrm{g}$ in fish ball. The results of the study showed limited Anti-Listeria activity of the bacteriocin in the first two weeks of the study. In addition, Naysin at the concentration of $1500 \mathrm{IU} / \mathrm{g}$ was not able to reduce Listeria to a partly acceptable level of 100 bacteria per gram food for healthy people even in the early days (Yin et al, 2007). In another study, the antimicrobial effects of Nisin with two combinations of Carvacrol and Thymol were studied on vegetative cells of Bacillus cereus. It was found that the simultaneous use of Nisin along with Thymol or Carvacrol was more impressive against $B$. cereus. Also, the review of Ettayebi et al. (2000) on the combined effect of Thymol and Nisin against $L$. monocytogenes and $B$. cereus, it was found that the use of combination of Nisin and Thymol reduced the amount of Nisin required to inhibit mentioned organisms significantly. It should be noted that in the case of using Nisin in high doses, there is the risk of creating and spreading the strains resistant to this 
bacteriocin (Ettayebi et al., 2000). In another study, synergistic effects of organic extracts of garlic on 6 strains of Minimum Inhibitory Concenterationand Nisin were studied in order to determine $L$. monocytogenes in a liquid medium culture model. The synergistic antibactericidal effects on strains of Listeria were observed when using these two materials together (Bhurinderet al., 2001).

Paul and colleagues (1999) used Nisin and Vegetable essential oils with di glycerides Esters of fatty acids for inhibiting $L$. monocytogenes bacteria. Among them, Carvacrol and Thymol were the most impressive compounds against $L$. monocytogenes, and after them, Eugenol, Cinnamic Aldehyde and Isoeugenol were effective, respectively. Also, among di glycerides Esters of fatty acids, di glycerol mono Laureth was the most impressive compound against $L$. monocytogenes. In the case of simultaneous use of these compounds, their study showed that can use Nisin and di glycerol mono Laureth to enhance anti-Listeria effect of vegetable compounds (Carvacrol, Thymol and Eugenol) with fewer doses. The vegetable essential oil in food materials is prevented adverse effects of vegetable essential oil on taste food (Pol and Smid, 1999). Roomiani (2012) investigated the effect of rosemary essential oil and Nisin on the growth of Streptococcus Iniae bacteria and concluded that at the temperature of $4{ }^{\circ} \mathrm{C}$, the cell growth delayed in all used concentrations of Nisin and rosemary separately until ninth day of storage. Also, their combination with each other delayed the cell growth of bacteria until third day. But at the temperature of $8^{\circ} \mathrm{C}$, applied concentrations of Nisin and rosemary could not inhibit the bacteria growth from the third day onwards (Roomiani, 2012).

\section{Conclusion}

In this researchthe antimicrobial properties of the combination of Nisin and peppermint essential oil in the growth of $L$. monocytogenes bacteria were studied. The results of this study state the importance of using natural preservatives as a suitable alternative to chemical preservatives and application of multiinhibitory parameters in reducing and eliminating L. monocytogenes. The amount of peppermint essential oil concentration that is required for inhibitory effects on bacteria is more of the amount of peppermint essential oil that is used to flavor food. For this reason, it may have adverse effects on the taste of food. Therefore, its combination with other preservatives such as Naysincan be a good solution. Because, the negative impact of peppermint essential oil on the taste of food can be largely prevented by reducing its concentration. This accompaniment as a synergistic effect can causes rising their inhibitory effects. Of course, it is still necessary to study more about antimicrobial properties of vegetative essential oils before using them as a food preservative.

\section{Ethical Statement}

All experiments were performed according to the protocols of approved scientific articles.

\section{Funding Information}

This study was conducted at personal expense.

\section{Author Contribution}

First Author: Conceptualization, Writing -review and editing; Data Curation, Formal Analysis, Investigation, Methodology, Visualization and Writing original Second Author: Supervision, Writing - review and editing. Third Author: Supervision, Writing -review and editing.

\section{Conflict of Interest}

The author(s) declare that they have no known competing financial or non-financial, professional, or personal conflicts that could have appeared to influence the work reported in this paper.

\section{References}

Bell, C. and Kyriakides, A. 2005. Listeria, A Practical Approach to the Organism and its Control in Foods, 2th, Blackwell publishing.

Bhurinder, S., Bernadette, F. and Martin, R. (2001). Synergistic inhibition of Listeria monocytogenesby nisinsnd garlic extract. Food Microbiology, 15: 133-139.

Boziaris IS, Nychas and GJE. Effect of nisin on growth boundaries of Listeria monocytogenesScott $A$, at various temperatures, $\mathrm{pH}$ and water activities. Food Microbiol. 2006; 8: 779 - 84.

Brandi G, Amagliani G, Schiavano G F, De Santi M and Sisti M, 2006. Activity of Brassica oleracea leaf juice on food borne pathogenic bacteria. Journal of Food Protection, 9: 2

Breukink, E, Wiedemann, I, Kraaij, C.V., Kuipers, O.P., Sahi, H.G. and Kruijff, B.D. Use of the cell wall precursor lipid II by a pore-forming peptide antibiotic. Sci. 1999; 286: 2361 - 4.

Bupesh, G., Amutha, C., Nandagopal, S., Ganeshumar, A., Sureshkumar, P. and Murali, K.S. 2007. Antibacterial activity of Menthapiperita L. (Peppermint) from leaf extracts - a medicinal plant. ActaAgriculturaeSlovenica, 89(1): 9- 73.

Curtis, G.D.W., R.G. Mitchell, A.F. King, and J. Emma. 2000. A selective differential medium for the isolation of Listeria monocytogenes. Journal of Food Microbiol. 8, 95-98.

De Arauza LJ, Jozalaa AF, Mazzola PG and VessoniPenna TC. Nisin biotechnological production and application: a review. Trend. Food Sci. Technol. 2009; 3 - 4: 146 - 54.

Delves-Broughton J and Gasson MJ. 1994.Natural antimicrobial systems and food preservation. Cab international. Oxon. pp: 99 - 131.

Dhanashree, B., Otta, S. K., Karunasagar, I.,Goebel, W., \&Karunasagar, 1.2008. Incidence of listeria spp. In clinical and food samoles in Mangalor, India. Food Microbiology, $20,447-453$. 
Dillon, R. T. Patel, 2003. Effect of cold smoking and storagetemperature on Listeria monocitogenesin saefoods. International Journal of Food Microbiology .62, 267-274.

Dillon, R., T. Patel, and S. Ratnam. 2003. Occurrence of Listeria in hot and cold smoked seafood ducts. International Journal of Food Microbiology. 22:73-77.

Duarte, M.C., Figueira, G.M., Sartoratto, A., Rehder, V.L. and Delarmelina, C. 2005. Anticandida activity of Brazilian medicinal plants. Journal of Ethnopharmacology, 97: 305- 311.

Ettayebi K, Yamani EIJ, Rossi-Hassani BD. Synergistic effects of nisin and thymol on antimicroibial activities in listeriamonocytogenes and Bacillus subtilis. FEMS Microbiol Lett 2000; 183(1): 191-195.

Farber, J. M. 2000b.Listeria monocytogenesin fish products. Journal of Food Protection. 54:922-924, 934.

Helander IM and Sandholm MT. Permeability barrier of the gram negative bacterial outer membrane with special reference to nisin. Int. J.foodMicrobiol. 2000; 60: 153 61.

Kuwano K, Shimizu T, Nagatoshi K, Nou Sand Sonomato K.2005. Dual antibacterial mechanisms of nisin against gram-positive and gram-negative bacteria. Int. J. Antimicrob. Ag. 26: $396-402$.

Leung, A.Y. and Foster, S. 1996. Encyclopedia of Common Natural Ingredients Used in Food, Drugs and Cosmetic. John Wiley and Sons, 355- 369.

Ma, B., Mayfield, M.B., Godfrey, B.J., Gold, M.H. 2004. Novel promoter sequence required for manganese regulation of manganese peroxidase isozyme 1 gene expression in Phanerochaetechrysosporium. Eukaryot. Cell, 3: 579588.

Misaghi A, Basti AA. Effect of Zataria multiflora Boiss. 2007. Essential oil and nisin on Bacillusereus ATCC 11778. Food control; 18 (9):1043 - 9.

Murdock CA, Cleveland J, Matthews KR and Chikindas ML. The synergistic effect of nisin and lactoferrin on the inhibition of Listeria monocytogenes and Escherichia coli 0157:H7. Lett. Appl. Microbiol. 2007; 3: 255 - 61.

Noriega, E., Newman, J., Saggers, E., Robertson, J., Laca, A., Díaz, M. and rocklehurst, T.F.2010. Antilisterial activity of carrots: effect of temperature and properties of different carrot fractions. Food Research International, 43(10): 2425-2431.

Oussalah M, Caillet S, Saucier L and Lacroix M. 2007. Inhibitory effects of selected plant essential oils on the growth of four pathogenic bacteria: E. coliO157: H7, Salmonella Typhimurium, Staphylococcus aureus and Listeria monocytogens. Food control; 18: 414 - 20.

Ozturk, A., Unlukara, A., Ipek, A. and Gurbuz, B., 2004. Effects of Salt Stress and Water Deficit on Plant Growth and Essential oil Content of Lemon Balm (Melissa officialis L.). Pak. J. Bot, 36(4): 787-792.
Peirce, A. 1999. The American Pharmaceutical Association practical guide to natural medicines. New York Journal: William Morrow and Company, 339: 937- 100.

Periago, P.M; Palop, A. and Fernandez, P.S;Combined effect of nisin, carvacrol and thymol on the viability of Bacillus cereus heat-treated vegetative cells. Food Sci. Technol. Int; 2001; 7: 487-492.

Pol IE and Smid EJ. Combined action of nisin and carvacrol on Basillus cereus and Listeriamonocytogen. Lett. Appl. Microbiol. 1999; 29: 166-70

Roomiani, L. (2012). Study of effect Rosmarinusofficinalis oil and nisin on the growth of Streptococcus iniae in lab conditions and fillets of rainbow trout (Oncorhynchus mykiss). A thesis submitted to the graduate studies office in the degree of Ph.D in fisheries science. Islamic azad university, science and research branch, pp. 160[In Farsi

Schuenzel KM and Harrison MA. 2002. Microbial antagonists of foodborne pathogens on fresh, minimally processed vegetables. J. Food Protect. 2002; 65 (12): 1909 - 15.

Shannon EM, Milillo SR, Johnson MG and Ricke SC. Inhibition of Listeria monocytogenes by exposure to a combination of nisin and coldpressed terpene less valencia oil. J. Food Sci.2011; 9: m600 - m604.

Singh, R., Shushni, A.M. and Belkheir, A. 2011. Antibacterial and antioxidant activities of Menthapiperita L. Arabian Journal of Chemistry, 1: 1- 5.

Skandamis P, Koutsoumanis K, Fasseas K and Nychas GJE. 2001. Inhibition of oregano essential oil and EDTA on Escherichia coli O157:H7. Ital. J.Food Sci.; 13: 65 - 75.

Smid EJ and Corris LGM.1999. Natural antimicrobials for food preservation. In: Shafiurrrahman. andbood of food preservation. Marcel Dekker. New York. pp: 285 - 308.

Sousa, A.A.S., Soares, P.M.G., de Almeida, A.N.S., Maia, A.R., de Souza, E.P. and Assreuy, A.M.S. 2010. Antispasmodic effect of Menthapiperita essential oil on tracheal smooth muscle of rats. Journal of Ethnopharmacol, 130: 433- 446.

Tyagi, A.K., Malik, A., Gottardi, D. and Guerzoni, M.E. 2012. Essential oil vapour and negative air ions: A novel tool for food preservation. Trends in Food Science and Technology, 26(2): 99-113.

Van Heusden HE, Knuijff B and Breukin E.2002.Lipid II induce a transmembrance orientation ofthe pore-forming peptide antibiotic nisin. Biochemistry; 41: 12171 - 8.

Velero M and Salmeron MS.2003. Antibacterial activity of essential oils against Bacillus cereus intyndallized carrot broth. Int. J. Food Microbiol. 85: 73 - 81.

Yamazaki K, Yamamoto T, Kawai $Y$ and Inoue N.2004. Enhancement of antilisterial activity ofessential oil constitutes by nisin and diglycerol fatty acid ester. Food Microbiol. 21: 283 - 9.

Yin, L., CW, W. and Jiang, S.T. 2007. Biopreservative effect of pediocin ACCEL on refrigerated seafood. Fish Science., 73(4):907- 912 